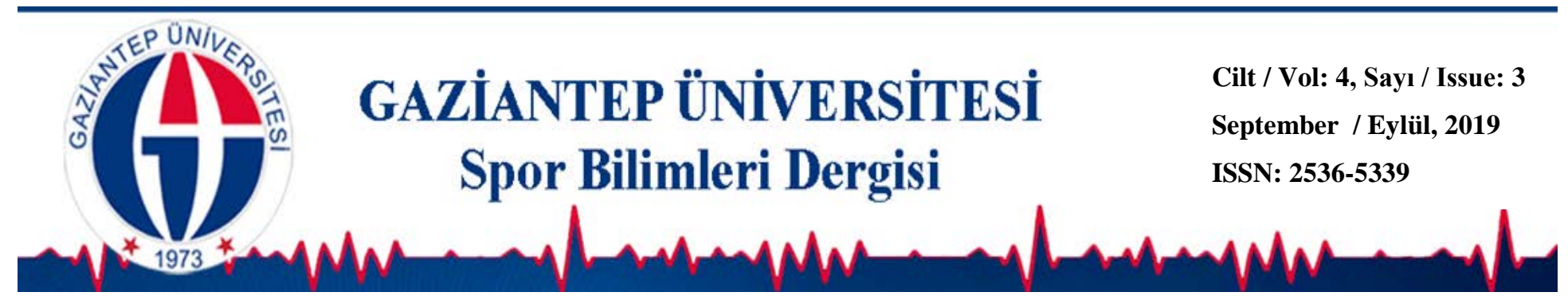

\title{
Beden Eğitimi Öğretmenlerinin Mesleki Yeterlik Düzeylerinin Farklı Değişkenler Açısından İncelenmesi \\ Elif AYDIN ${ }^{1 *} \mathbb{D}$
}

${ }^{1}$ Gümüşhane Üniversitesi, Beden Eğitimi ve Spor Yüksekokulu, GÜMÜŞHANE

DOI: 10.31680/gaunjss.623361

Orijinal Makale / Original Article

Geliş Tarihi / Received: 07.08.2019 Kabul Tarihi / Accepted: 20.09.2019 Yayın Tarihi / Published: 22.09.2019

Öz

Bu araştırmanın amacı, beden eğitimi öğretmenlerinin mesleki yeterlilik düzeyleri arasındaki ilişkileri incelemektir. Araştırmada beden eğitimi öğretmenlerinin mesleki yeterlilik düzeyleri belirlenmiş; cinsiyet, mesleki deneyim, okulun bulunduğu yerleşim yeri, okul içinde sportif faaliyet düzenleme, okulun alt yapı değişkenleri mesleki yeterlilik alt boyutları açısından karşılaştırılmıştır. Araştırmada, nicel araştırma desenlerinden tarama (survey) modeli kullanılmıştır. Araştırma grubunu 2018-2019 eğitim-öğretim güz yarıyılında Trabzon II Milli Eğitim Müdürlügü̈ne bağlı Ortaokul ve Liselerde görev yapan $43(\% 27,9)$ kadın ve $111(\% 72,1)$ erkek olmak üzere toplam 154 Beden Eğitimi Öğretmeni oluşturmaktadır. Araştırma verilerinin toplanmasında, kişisel bilgi formu, (Ünlü ve diğ., 2008) tarafından geliştirilen "Beden eğitimi öğretmeni yeterlilik ölçeği” kullanılmıştır. Araştırma verilerinin analizinde SPSS 21.00 programı kullanılmıştır. Ayrıca verilerin analizi için tanımlayıcı istatistiklerin yanı sıra; T testi, one-way Anova ve Tukey testlerinden yararlanılmıştır. Araştırma sonuçlarına göre, beden eğitimi öğretmen yeterliği alt boyutlarının tümü olan kişisel ve mesleki gelişim, öğrenciyi tanıma, öğrenme ve öğretme süreci, öğrenmeyi, gelişimi izleme ve değerlendirme, okul aile ve toplum ilişkileri ve program ve içerik bilgisi ile cinsiyet, mesleki deneyim, okulun bulunduğu yerleşim yeri, okul içinde sportif faaliyet düzenleme, okulun alt yapı değişkenleri açısından anlamlı farklılıklar olduğu tespit edilmiştir. Bulgular literatür ışığında tartışıımış ve ortaya çıkan sonuçlar doğrultusunda öneriler geliştirilmiştir.

Anahtar Kelimeler: Beden Eğitimi Öğretmen Yeterliliği, Beden Eğitimi Öğretmeni

\section{Investigation of the Vocational Proficiency of Physical Education Teachers in Terms of Different Variables}

\begin{abstract}
The aim of this research is to investigate the vocational competence levels of physical education teachers. In the research, professional competence levels of physical education teachers were determined; gender, professional experience, place of residence of the school, sporting activities within the school, infrastructure of the school were compared in terms of professional competence sub-dimensions. In this research, survey model which is one of the quantitative research designs was used. The research group consisted of 154 Physical Education Teachers (43 (27.9\%) female and 111 (72.1\%) male) working in Secondary and High Schools of Trabzon Provincial Directorate of National Education in 2018-2019 academic year.Personal data form, Ünlü Physical Education Teacher Qualification Scale geliştiril developed by Ünlü (et al., 2008) was used in the collection of research data. SPSS 21.00 program was used in the analysis of the research data. In addition to descriptive statistics for the analysis of data; T test, one-way Anova and Tukey tests were used. According to the results of the research, personal and professional development which are all of the sub-dimensions of physical education teacher competence, student recognition, learning and teaching process, learning, monitoring and evaluation of development, school, family and community relations and program and content knowledge, gender, professional experience, school It was determined that there were significant differences in terms of settlement, sporting activities within the school, infrastructure of the school. The findings were discussed in the light of the literature and recommendations were developed in line with the results.

Keywords: Physical Education Teacher Qualification, Physical Education Teacher
\end{abstract}

* Sorumlu Yazar: Elif AYDIN

E-mail:aydinelif_61@hotmail.com 


\section{Giriş}

Günümüz iletişim ve bilgi çağı, eğitim ihtiyacını giderek arttırmakta ve çağa uyum sağlayacak özelliklere sahip nitelikli eğitim sistemi ve okulların ancak nitelikli öğretmenlerle gerçekleşeceğini ortaya koymaktadır (Özkan, 2010). Öğretmen niteliği toplumun gelişmişlik düzeyini, insan anlayışını etkilemektedir (Davran, 2006). Bireyleri bedensel ve zihinsel açıdan bütünleşik olarak geliştirmek, çevresel faktörler ve bireysel özellikler doğrultusunda öğretim planı tasarlamak beden öğretmenlerinin görevidir. Aynı zamanda beden eğitimi ve spor öğretmenleri, spor aktiviteleri ve beden eğitiminin eğitim kurumu çatısı altında gerçekleştirilmesini sağlayarak yön vermektedirler (Seçkin ve Başbay 2013).

Beden eğitimi dersi bireylere spor yapma alışkanlığı kazandırmakta ve sporun hayat felsefesi haline gelmesini sağlamaktadır. Spor yapma alışkanlığı kazanmış bireyler, hayattan daha çok zevk almakta, sorumluluk duyguları gelişmekte dolayısıyla daha mutlu olmaktadırlar. Böylelikle beden eğitimi dersinin sosyal statüye sahip bireyleri kapsayan bir toplum oluşturduğu gerçeği ortaya çıkmaktadır (Aras, 2013).Beden eğitimi, amaçlarına yönelik aktiviteleri ile bireylere öz yeterlilik kazandırmak, ideal edinmesini sağlamak ve yönlendirmek gibi görevler üstlenmektedir. Beden eğitimi bedensel direnç kazanımına, disiplin duygusunun artmasına ve bilinçlenmeye yardımcı olmaktadır (Seçme, 2008).

Beden eğitimi ve spor öğretmenlerinin başlıca görevleri; milli eğitimin temel prensipleri doğrultusunda bireylerin ruhsal ve fikirsel gelişimlerini sağlamak, okul dâhilinde ya da haricindeki spor aktivitelerini yaptırmak ve organize etmektir (Karakuş, 2005).Başarılı öğretmen niteliğine kavuşmak için çağdaş bilgi birikimini kavramış olmak, toplumsal gerekliliği karşılayabilmek ve bireylerin gelişmesine katkı sağlamak gibi yeterliklere sahip olmak gerekir. Yetiştirdiği bireylerin başarısıyla toplumsal gelişimi sağlayan, güçsüzlüğü veya yetersizliği ile toplumsal gelişmeye ket vuran öğretmen kalkınmada önemli bir konum teşkil etmektedir. Öğretmenler zorlayıcı olanaklar ve standartlarla değerlendirilirken görevlerini başarıyla yerine getirmeleri için gerekli olan sosyo- ekonomik şartlar, maaş düzeyi, eğitim teknolojisi ve eğitim programları yetersiz kalmaktadır. Söz konusu koşullar altında eğitimde verimliliğe ulaşabilme sorunsalı oldukça önem arz etmektedir. Bu nedenle soruna yönelik çözüm arayan öğretmenin iş yükü fazlasıyla ağırdır (Öksüzoğlu, 2009). 
Yeterliğe sahip bir beden eğitimi öğretmeni, göreve ilişkin sorumlulukları yerine getirebilmek için gerekli bilgi, beceri, anlayış ve tutuma sahip olmalıdır (Ünlü 2008).Çağdaş eğitim ve öğretim sistemine uygun nitelikli bir beden eğitim öğretmeni, öğrenci ile okul içinde ve gerekirse okul dışında etkileşim halinde bulunmalı, sportif faaliyetler düzenlemeli, okul idaresi ve velilerle gereklilik dahilinde iletişim halinde bulunmalı, eğitim öğretim plan ve programını uygulamalı ve süreci yönetmelidir(Seçkin ve Başbay, 2013). Eğitim programı çatısı altında bulunan ve oldukça önem teşkil eden beden eğitimi derslerinin gereğinin yerine getirilip amacına ulaşılabilmesi ve kişilerde istenilen davranış değişikliklerinin meydana getirilebilmesi ancak nitelikli, yenilikçi, yaratıcı ve gelişime açık beden öğretmenleriyle mümkün olabilmektedir (Ünlü, 2008).

Dolayısıyla eğitim sistemimizin amaçlarına ulaşmasında üzerinde durulması gereken konu olarak öğretmenlerin sahip olduğu mesleki yeterlilik düzeylerinin belirlenmesi önemle ele almayı zorunlu kılmıştır. Bu araştırmanın bu konudaki eksikliği gidererek alana fayda sağlayacağı öngörülmektedir. Bu araştırmada temel amaç; beden eğitimi öğretmenlerinin mesleki yeterlilik düzeyi alt boyutları ile cinsiyet, mesleki deneyim, okulun bulunduğu yerleşim yeri, okul içinde sportif faaliyet düzenleme, okulun alt yapısı gibi bağımsız değişkenler arasında anlamlı fark olup olmadığını belirlemektir.

\section{Materyal ve Metot}

Araştırma Modeli: Beden eğitimi öğretmenlerinin mesleki yeterlilik düzeylerinin incelenmesini amaçlayan bu çalışmada, betimsel araştırma yöntemi içerisinde sıklıkla kullanılan nicel araştırma desenlerinden tarama (survey) modeli kullanılmıştır.

Araştırma Grubu: Araştırma grubunu, Trabzon İl Milli Eğitim Müdürlüğü'ne bağlı lise ve ortaokullarda 2018-2019 eğitim öğretim güz yarıyılında görev yapmakta olan 43 $(\% 27,9)$ kadın ve $111(\% 72,1)$ erkek olmak üzere toplam 154 Beden Eğitimi Öğretmeni oluşturmaktadır.

\section{Veri Toplama Araçları}

Araştırma kapsamında Beden Eğitimi Öğretmenlerine, araştırmacı tarafından geliştirilen "Kişisel Bilgi Formu", ayrıca "Beden Eğitimi Öğretmenleri Yeterlik Ölçeği" uygulanmıştır. 


\section{Kişisel Bilgi Formu}

Araştırma kapsamındaki beden eğitimi öğretmenlerine ilişkin kişisel bilgileri edinmek amacıyla araştırmacı tarafından geliştirilmiştir. Mesleki yeterlik durumlarını etkileyeceği düşünülen değişkenlerin yer aldığı cinsiyet, mesleki deneyim, okulun bulunduğu yerleşim yeri, okul içinde sportif faaliyet düzenleme, okulun alt yapı durumları ile ilgili sorular sorulmuştur.

\section{Beden Eğitimi Öğretmenleri Yeterlik Ölçeği}

Ölçek, beden eğitimi öğretmenlerinin öğretim sürecindeki yeterlilik algılarını ölçmek amacıyla geliştirilmiştir (Ünlü ve ark. 2008 ). Ölçek toplam 78 maddeden ve "Kişisel ve Meslekî Değerler - Meslekî Gelişim, Öğrenciyi Tanıma, Öğrenme ve Öğretme Süreci, Öğrenmeyi, Gelişimi izleme ve Değerlendirme, Okul - Aile ve Toplum İlişkileri, Program ve içerik Bilgisi" olmak üzere toplam 6 boyuttan oluşmuştur. Literatüre göre faktör örüntüsü oluşturulurken 0,30 ile 0,40 aralığında değişen faktör kesme noktası alınabilmektedir (Neale ve Liebert, 1980). Bu çalışmada maddeler için kesme noktası katsayısı 0,40 olarak alınmıştır. "Compenant ve Varimax Faktör Analizleri" sonucunda 3 maddenin faktör yükü 0,40 kesme noktasının altında bir değere sahip olduğu için ölçeğe dahil edilmemiştir. Ölçeğe uygulanan "Varimax Rotasyon" uygulanmıştır. Çalışma sonucunda faktör yükü 0,40'ın üstünde olan ve 6 faktörde toplanan maddeler için ait oldukları alt boyut içerisinde madde toplam korelasyonları hesaplanmıştır. Hesaplanan güvenirlik katsayıları ölçeğin tüm alt boyutları için sırasıyla şöyledir: Kişisel ve Mesleki Gelişim 0.88, Öğrenciyi Tanıma 0.81, Öğrenme ve Öğretme Sürecinde Yeterlik 0.93, Öğrenmeyi, Gelişimi izleme ve Değerlendirme 0.71, Okul-Aile ve Toplum ilişkileri 0.87, Program ve içerik Bilgisi 0.65. Güvenirlikle ilgili çalışmalarda 0.65 ve üstündeki katsayıların yeterli olduğu ileri sürülmektedir (Cronbach, 1990). Bu açıdan bu ölçeğin alt boyutlarından elde edilen güvenirlik katsayılarının yeterli ve yüksek olduğu söylenebilir

\section{Verilerin Analizi}

Verilere ait analiz, SPSS (Statistical Package for Social Sciences) 21.0 paket programı ile gerçekleştirilmiştir. Araştırmada, beden eğitimi öğretmenlerinin mesleki yeterlik düzeyi ortalamalarının saptanmasında "aritmetik ortalama ve standart sapma", cinsiyet değişkeni açısından T testi tekniğinden yararlanılmıştır. Ayrıca 
beden eğitimi öğretmenlerinin, mesleki yeterlik düzeyi alt boyutları puan ortalamalarının; mesleki deneyim, okulun bulunduğu yerleşim yeri, okul içinde sportif faaliyet düzenleme, okulun alt yapı durumu değişkenleri açısından değişip değişmediğini tespit etmek maksadıyla tek yönlü varyans analizi (One-Way Anova) kullanılmıştır. Yapılan varyans analizlerinde ise varyansın kaynağını tespit etmek amacıyla da Tukey testine başvurulmuştur.

\section{Bulgular}

Bu bölümde, araştırmanın amacı doğrultusunda belirlenen problem ve alt problemlerle ilgili elde edilen bulgular sırasıyla tablolaştırılmış ve araştırma grubu ile ilgili tanımlayıcı bulgulara yer verilmiştir.

Tablo 1. Katılımcıların cinsiyet parametresine göre öğretmen yeterliği alt boyutlarına dair $\mathrm{t}$ testi sonuçları

Değişkenler

\begin{tabular}{|c|c|c|c|c|c|c|}
\hline Değişkenler & Cinsiyet & $\mathbf{N}$ & Ortalama & Ss & $\mathbf{t}$ & $\mathbf{P}$ \\
\hline \multirow{2}{*}{ Öğrenme ve Öğretme Süreci } & Kadın & 43 & 4,15 &, 53182 & \multirow{2}{*}{2,716} & \multirow{2}{*}{, $007 *$} \\
\hline & Erkek & 111 & 3,86 & ,62917 & & \\
\hline \multirow{2}{*}{ Okul - Aile ve Toplum ilişkileri } & Kadın & 43 & 3,87 & ,63551 & \multirow{2}{*}{1,005} & \multirow{2}{*}{,316* } \\
\hline & Erkek & 111 & 3,74 & ,74454 & & \\
\hline \multirow{2}{*}{$\begin{array}{c}\text { Öğrenmeyi, Gelişimi izleme ve } \\
\text { Değerlendirme }\end{array}$} & Kadın & 43 & 2,50 & ,67436 & \multirow{2}{*}{$-3,862$} & \multirow{2}{*}{, $000^{*}$} \\
\hline & Erkek & 111 & 2,85 & ,43165 & & \\
\hline \multirow{2}{*}{ Öğrenciyi Tanıma } & Kadın & 43 & 2,50 & ,69859 & \multirow{2}{*}{$-2,906$} & \multirow{2}{*}{, $004^{*}$} \\
\hline & Erkek & 111 & 2,86 & ,69063 & & \\
\hline \multirow{2}{*}{ Program ve İçerik Bilgisi } & Kadın & 43 & 3,18 & 39111 & \multirow{2}{*}{$-2,943$} & \multirow{2}{*}{, $004^{\star}$} \\
\hline & Erkek & 111 & 3,40 & ,44795 & & \\
\hline \multirow{2}{*}{ Kişisel ve Mesleki Gelişim } & Kadın & 43 & 2,12 & 27130 & \multirow{2}{*}{$-3,069$} & \multirow{2}{*}{,003* } \\
\hline & Erkek & 111 & 2,33 & ,42325 & & \\
\hline
\end{tabular}
$* \mathrm{p}<0.05$

Yapılan analiz neticesine göre beden eğitimi öğretmen yeterliği alt boyutlarının tümü olan kişisel ve mesleki gelişim ( $t=-3,069, p<0.05)$, öğrenciyi tanıma $(t=-2,906$, $p<0.05)$, öğrenme ve öğretme süreci $(t=2,716, p<0.05)$, öğrenmeyi, gelişimi izleme ve değerlendirme $(t=-3,862, p<0.05)$, okul aile ve toplum ilişkileri $(t=1,005, p<0.05$ ve program ve içerik bilgisi $(t=-2,943, p<0.05)$ ile cinsiyet değişkeni açısından anlamlı farklılıklar mevcuttur.

Buna göre Kişisel ve Mesleki Gelişim alt boyutunda erkek katılımcıların $(X=2,33)$ beden eğitimi öğretmeni yeterliklerinin kadın katılımcılardan $(X=2,12)$ anlamlı düzeyde yüksek olduğu belirlenmiştir. Öğrenciyi Tanıma alt boyutunda erkek katılımcıların $(X=2,86)$ beden eğitimi öğretmeni yeterliklerinin kadın katılımcılardan $(X=2,50)$ anlamlı düzeyde yüksek olduğu belirlenmiştir. Öğrenme ve Öğretme Süreci 
alt boyutunda kadın katılımcıların $(X=4,15)$ beden eğitimi öğretmeni yeterliklerinin erkek katılımcılardan $(X=3,86)$ anlamlı düzeyde yüksek olduğu belirlenmiştir.

Öğrenmeyi, Gelişimi izleme ve Değerlendirme alt boyutunda erkek katılımcıların $(X=2,85)$ beden eğitimi öğretmeni yeterliklerinin kadın katılımcılardan $(X=2,50)$ anlamlı düzeyde yüksek olduğu belirlenmiştir. Okul - Aile ve Toplum ilişkileri alt boyutunda kadın katılımcıların $(X=3,87)$ beden eğitimi öğretmeni yeterliklerinin erkek katılımcılardan $(X=3,74)$ anlamlı düzeyde yüksek olduğu belirlenmiştir. Program ve içerik Bilgisi alt boyutunda erkek katılımcıların $(X=3,40)$ beden eğitimi öğretmeni yeterliklerinin kadın katılımcılardan $(X=3,18)$ anlamlı düzeyde yüksek olduğu belirlenmiştir.

Tablo 2. Katılımcıların mesleki deneyim değişkenine göre öğretmen yeterlik alt boyutlarına ilişkin tek yönlü anova sonuçları

\begin{tabular}{|c|c|c|c|c|c|c|c|c|c|c|}
\hline Alt Boyut & $\begin{array}{l}\text { Mesleki } \\
\text { Deneyim }\end{array}$ & $\mathbf{N}$ & $x$ & SS & Var. K. & KT & sd & KO & $\mathbf{F}$ & $\mathbf{P}$ \\
\hline \multirow{5}{*}{$\begin{array}{c}\text { Program } \\
\text { ve İçerik } \\
\text { Bilgisi }\end{array}$} & $1-5$ & 29 & 3,49 & ,38153 & $\begin{array}{c}\text { Gruplar } \\
\text { arası }\end{array}$ & 2,299 & 3 & ,766 & 4,132 & \multirow[t]{2}{*}{, $008^{\star}$} \\
\hline & $6-10$ & 42 & 3,39 & ,45447 & $\begin{array}{c}\text { Gruplar } \\
\text { içi }\end{array}$ & 27,822 & 150 & ,185 & & \\
\hline & $11-15$ & 53 & 3,18 & ,45137 & Toplam & 30,121 & 153 & & & \\
\hline & $\begin{array}{l}16 \text { ve } \\
\text { üzeri }\end{array}$ & 30 & 3,42 & ,40187 & & & & & & \\
\hline & Total & 154 & 3,34 & ,44370 & & & & & & \\
\hline \multirow{5}{*}{$\begin{array}{l}\text { Öğrenciyi } \\
\text { Tanıma }\end{array}$} & $1-5$ & 29 & 2,93 & 90470 & $\begin{array}{c}\text { Gruplar } \\
\text { arası }\end{array}$ & 6,529 & 3 & 2,176 & \multirow[t]{2}{*}{4,631} & \multirow[t]{2}{*}{, $004^{\star}$} \\
\hline & $6-10$ & 42 & 2,78 & ,65486 & $\begin{array}{c}\text { Gruplar } \\
\text { içi }\end{array}$ & 70,488 & 150 & ,470 & & \\
\hline & $11-15$ & 53 & 2,51 & ,67609 & Toplam & 77,017 & 153 & & & \\
\hline & $\begin{array}{l}16 \text { ve } \\
\text { üzeri }\end{array}$ & 30 & 3,04 & ,46307 & & & & & & \\
\hline & Total & 154 & 2,76 & ,70949 & & & & & & \\
\hline
\end{tabular}

${ }^{*} \mathrm{p}<0.05$

Yapılan analiz sonuçlarına göre katılımcıların beden eğitimi öğretmeni olma yeterlikleri ile mesleki deneyimleri arasında öğrenciyi tanıma $[F(3 / 150)=4,631$, $p<0.05)$ ile program ve içerik bilgisi $[F(3 / 150)=4,132, p<0.05)$ boyutlarında anlamlı farkın olduğu belirlenmiştir. Öteki alt boyutlarda mesleki deneyim değişkenine göre anlamlı bir farklılık bulunmamıştır ( $p>.05)$.

Ortaya çıkan farkın kaynağını belirlemek amacıyla Tukey Post Hoch istatistiği gerçekleştirilmiştir. Öğrenciyi tanıma alt boyutunda mesleki deneyimi 16 ve üzeri olanların puanlarının $(X=3,04)$ mesleki deneyimi 11-15 yıl olanların puanlarından $(X=2,51)$ anlamlı düzeyde yüksek olduğu görülmektedir. Buna göre 1-5, 6-10 ve $11-$ 15 mesleki deneyim yılları arasından 16 ve üzeri lehine anlamlı bir fark tespit 
edilmiştir. Program ve içerik Bilgisi boyutunda ise mesleki tecrübe süresi 1 ila 5 yıl olanların puanlarının $(X=3,49)$ mesleki tecrübe süresi 11-15 yıl olanların puanlarından $(X=2,51)$ anlamlı düzeyde yüksek olduğu görülmektedir. Buna göre 6$1011-15,16$ ve üzeri mesleki deneyim yılları arasından 1-5 lehine anlamlı bir fark olduğu saptanmıştır.

Tablo 3. Katılımcıların Okulun Alt Yapı Parametresine Göre Öğretmen Yeterlik Alt Boyutlarına İlişkin Tek Yönlü Anova Sonuçları

\begin{tabular}{|c|c|c|c|c|c|c|c|c|c|c|}
\hline Alt Boyut & $\begin{array}{l}\text { Mesleki } \\
\text { Deneyim }\end{array}$ & $\mathbf{N}$ & $x$ & sS & Var. K. & KT & sd & KO & $F$ & $\mathbf{P}$ \\
\hline \multirow{4}{*}{ Öğrenciyi Tanıma } & Yeterli & 85 & 2,62 & ,76976 & $\begin{array}{l}\text { Gruplar } \\
\text { arası }\end{array}$ & 4,251 & 3 & 2,126 & 4,411 & \multirow[t]{2}{*}{,014* } \\
\hline & $\begin{array}{c}\text { Kısmen } \\
\text { yeterli }\end{array}$ & 50 & 2,99 & ,58361 & $\begin{array}{c}\text { Gruplar } \\
\text { içi }\end{array}$ & 72,766 & 150 & ,482 & & \\
\hline & Yetersiz & 19 & 2,82 &, 59180 & Toplam & 77,017 & 153 & & & \\
\hline & Total & 154 & 2,76 & ,70949 & & & & & & \\
\hline \multirow{4}{*}{$\begin{array}{l}\text { Öğrenmeyi, } \\
\text { Gelişimi izleme ve } \\
\text { Değerlendirme }\end{array}$} & Yeterli & 85 & 2,63 & ,54595 & $\begin{array}{c}\text { Gruplar } \\
\text { arası }\end{array}$ & 2,844 & 3 & 1,422 & \multirow[t]{2}{*}{5,283} & \multirow[t]{2}{*}{, $006^{\star}$} \\
\hline & $\begin{array}{c}\text { Kısmen } \\
\text { yeterli }\end{array}$ & 50 & 2,93 & ,47356 & $\begin{array}{c}\text { Gruplar } \\
\text { içi }\end{array}$ & 40,637 & 150 & ,269 & & \\
\hline & Yetersiz & 19 & 2,82 &, 50616 & Toplam & 43,481 & 153 & & & \\
\hline & Total & 154 & 2,75 &, 53309 & & & & & & \\
\hline \multirow{4}{*}{$\begin{array}{l}\text { Okul - Aile ve } \\
\text { Toplum İlişkileri }\end{array}$} & Yeterli & 85 & 3,94 & ,56591 & $\begin{array}{c}\text { Gruplar } \\
\text { arası }\end{array}$ & 6,706 & 3 & 3,353 & \multirow[t]{2}{*}{7,056} & \multirow[t]{2}{*}{, $001^{*}$} \\
\hline & $\begin{array}{c}\text { Kısmen } \\
\text { yeterli }\end{array}$ & 50 & 3,68 & ,86054 & $\begin{array}{c}\text { Gruplar } \\
\text { içi }\end{array}$ & 71,752 & 150 & ,475 & & \\
\hline & Yetersiz & 19 & 3,32 & ,68981 & Toplam & 78,459 & 153 & & & \\
\hline & Total & 154 & 3,78 & ,71610 & & & & & & \\
\hline \multirow{4}{*}{$\begin{array}{l}\text { Öğrenme ve } \\
\text { Öğretme Süreci }\end{array}$} & Yeterli & 85 & 4,03 &, 56559 & $\begin{array}{c}\text { Gruplar } \\
\text { arası }\end{array}$ & 4,692 & 3 & 2,346 & \multirow{2}{*}{6,631} & \multirow[t]{2}{*}{, $002^{\star}$} \\
\hline & $\begin{array}{l}\text { Kısmen } \\
\text { yeterli }\end{array}$ & 50 & 3,96 & ,65750 & $\begin{array}{l}\text { Gruplar } \\
\text { içi }\end{array}$ & 53,420 & 150 & ,354 & & \\
\hline & Yetersiz & 19 & 3,49 & ,54602 & Toplam & 58,112 & 153 & & & \\
\hline & Total & 154 & 3,94 & ,61629 & & & & & & \\
\hline \multirow{4}{*}{$\begin{array}{c}\text { Kişisel ve Mesleki } \\
\text { Gelişim }\end{array}$} & Yeterli & 85 & 2,40 & ,39088 & $\begin{array}{c}\text { Gruplar } \\
\text { arası }\end{array}$ & 3,043 & 3 & 1,522 & \multirow{2}{*}{10,855} & \multirow{2}{*}{,000* } \\
\hline & $\begin{array}{c}\text { Kısmen } \\
\text { yeterli }\end{array}$ & 50 & 2,10 & ,33346 & $\begin{array}{c}\text { Gruplar } \\
\text { içi }\end{array}$ & 21,166 & 150 & ,140 & & \\
\hline & Yetersiz & 19 & 2,18 & ,40027 & Toplam & 24,210 & 153 & & & \\
\hline & Total & 154 & 2,27 & ,39778 & & & & & & \\
\hline
\end{tabular}

Yapılan analiz sonuçlarına göre katılımcıların beden eğitimi öğretmeni olma yeterlikleri ile alt yapı değişkeni arasında Öğrenmeyi, Gelişimi izleme ve Değerlendirme $[F(3 / 150)=5,283, \quad p<0.05)$ ile Okul - Aile ve Toplum İlişkileri $[F(3 / 150)=7,056, p<0.05) \quad K i s ̧ i s e l$ ve Mesleki Gelişim $[F(3 / 150)=10,855, p<0.05)$ Öğrenme ve öğretme süreci $[F(3 / 150)=6,631, p<0.05)$ öğrenciyi tanıma $[F(3 / 150)=4,411, p<0.05)$ boyutlarında anlamlı farkın olduğu saptanmıştır.

Ortaya çıkan farkın kaynağını belirlemek amacıyla Tukey Post Hoch istatistiği gerçekleştirilmiş̧ir. Buna göre kişisel ve mesleki gelişim boyutunda altyapı yeterli diyenlerin puanları $(X=2,40)$ kısmen yeterli diyenlerin puanlarından $(X=2,10)$ anlamlı düzeyde yüksektir. 
Öğrenciyi tanıma boyutunda alt yapı kısmen yeterli diyenlerin puanları $(X=2,99)$ alt yapı yeterli diyenlerin puanlarından $(X=2,62)$ anlamlı düzeyde yüksektir. Öğrenme ve öğretme süreci boyutunda alt yapı yeterli diyenlerin puanları $(X=4,03)$ alt yapı yetersiz diyenlerin puanlarından $(X=3,49)$ anlamlı düzeyde yüksektir. Okul- aile ve toplum boyutunda alt yapı yeterli diyenlerin puanları $(X=3,94)$ alt yapı yetersiz diyenlerin puanlarından $(X=3,32)$ anlamlı düzeyde yüksektir. Öğrenmeyi, Gelişimi izleme ve Değerlendirme boyutunda ise alt yapı kısmen yeterli diyenlerin puanları $(X=2,93)$ alt yapı yeterli diyenlerin puanlarından $(X=2,63)$ anlamlı düzeyde yüksektir.

Tablo 4. Katılımcıların Okul İçinde Sportif Faaliyet Düzenleme Değişkenine Göre Öğretmen Yeterlik Alt Boyutlarına Illişkin Tek Yönlü Anova Sonuçları

\begin{tabular}{|c|c|c|c|c|c|c|c|c|c|c|}
\hline Alt Boyut & $\begin{array}{r}\text { Sportif } \\
\text { faaliyet }\end{array}$ & $\mathbf{N}$ & $x$ & SS & Var. K. & $\mathrm{KT}$ & sd & KO & $\mathbf{F}$ & $\mathbf{P}$ \\
\hline \multirow{4}{*}{$\begin{array}{l}\text { Program ve } \\
\text { İçerik Bilgisi }\end{array}$} & Evet & 94 & 3,41 & 42970 & $\begin{array}{c}\text { Gruplar } \\
\text { arası }\end{array}$ & 1,927 & 2 & ,963 & 5,160 & \multirow{2}{*}{, $007^{\star}$} \\
\hline & Hayır & 24 & 3,40 & 38712 & $\begin{array}{c}\text { Gruplar } \\
\text { içi }\end{array}$ & 28,194 & 151 & 187 & & \\
\hline & Kısmen & 36 & 3,14 & ,46524 & Toplam & 30,121 & 153 & & & \\
\hline & Total & 154 & 3,34 &, 44370 & & & & & & \\
\hline \multirow{4}{*}{$\begin{array}{l}\text { Öğrenciyi } \\
\text { Tanıma }\end{array}$} & Evet & 94 & 2,86 & ,54705 & $\begin{array}{c}\text { Gruplar } \\
\text { arası }\end{array}$ & 12,404 & 2 & ,963 & \multirow{2}{*}{14,495} & \multirow{2}{*}{, $000^{*}$} \\
\hline & Hayır & 24 & 3,12 & ,99060 & $\begin{array}{c}\text { Gruplar } \\
\text { içi }\end{array}$ & 64,613 & 151 & ,187 & & \\
\hline & KIsmen & 36 & 2,28 & ,63723 & Toplam & 77,017 & 153 & & & \\
\hline & Total & 154 & 2,76 & ,70949 & & & & & & \\
\hline \multirow{4}{*}{$\begin{array}{l}\text { Öğrenmeyi, } \\
\text { Gelişimi izleme } \\
\text { ve } \\
\text { Değerlendirme }\end{array}$} & Evet & 94 & 2,86 & 39915, & $\begin{array}{c}\text { Gruplar } \\
\text { arası }\end{array}$ & 7,701 & 2 & ,963 & \multirow{2}{*}{16,249} & \multirow{2}{*}{, $000^{*}$} \\
\hline & Hayır & 24 & 2,93 & 48693, & $\begin{array}{c}\text { Gruplar } \\
\text { içi }\end{array}$ & 35,780 & 151 & ,187 & & \\
\hline & KIsmen & 36 & 2,35 & ,66568 & Toplam & 43,481 & 153 & & & \\
\hline & Total & 154 & 2,75 & ,53309 & & & & & & \\
\hline
\end{tabular}

Analiz neticesine göre katılımcıların beden eğitimi öğretmeni olma yeterlikleri ile okul içinde sportif faaliyet düzenleme durumu arasında Öğrenmeyi, Gelişimi izleme ve Değerlendirme $[F(2 / 151)=16,249, \quad p<.05]$, ile program ve içerik bilgisi $[F(2 / 151)=5,160, p<.05]$, öğrenciyi tanıma $[F(2 / 151)=14,495, p<.05]$, boyutlarında anlamlı farkın olduğu belirlenmiştir. Diğer alt boyutlarda mesleki deneyim parametresine göre anlamlı bir farklııık belirlenememiştir ( $p>.05)$.

Ortaya çıkan farkın kaynağını saptamak amacıyla Tukey Post Hoch istatistiği gerçekleştirilmiştir. İstatistiğe göre kişisel program ve içerik bilgisi boyutunda düzenli sportif faaliyet yapmaya evet yanıtını verenlerin puanları $(X=, 3,41)$ kısmen yanıtını verenlerin puanlarından $(X=3,14)$ anlamlı düzeyde yüksektir. Öğrenciyi tanıma boyutunda düzenli sportif faaliyet yapmaya hayır yanıtını verenlerin puanları $(X=3,12)$ kısmen yanııını verenlerin puanlarından $(X=2,28)$ anlamlı düzeyde yüksektir. Öğrenmeyi, Gelişimi izleme ve Değerlendirme boyutunda ise düzenli sportif faaliyet 
yapmaya hayır yanıtını verenlerin puanları $(X=2,93)$ kısmen yanıtını verenlerin puanlarından $(X=2,35)$ anlamlı düzeyde yüksektir.

\section{Tartışma ve Sonuç}

$\mathrm{Bu}$ araştırmada beden eğitimi öğretmenlerinin mesleki yeterlilik düzeyleri ele alınmıştır. Bunun yanı sıra mesleki deneyim, okulun konumu, cinsiyet, okul içinde sportif faaliyet düzenleme, okulun alt yapı değişkenleri mesleki yeterlilik alt boyutları açısından ele alınmıştır.

Yapılan analiz sonuçlarına göre katılımcıların Mesleki Yeterlilik alt boyutlarından olan kişisel ve mesleki gelişim, öğrenciyi tanıma, öğrenme ve öğretme süreci, öğrenmeyi, gelişimi izleme ve değerlendirme, program ve içerik bilgisi ile cinsiyet değişkeni arasında anlamlı düzeyde bir fark bulunmuştur. Literatürde, bu çalışmadaki bulgulara benzer şekilde mesleki yeterlik üzerinde cinsiyetin belirleyici bir etkiye sahip olduğu saptanmıştır (Çifçili 2007, Terekeci 2010, Sünbül ve Arslan 2007). Yapılan Yapılan bazı araştırmalarda mesleki yeterlilik ile cinsiyet değişkeni arasında anlamlı bir farklılık göstermediği sonucuna ulaşılan çalışmalarda mevcuttur (Mirzeoğlu ve ark. 2007, Tschannen-Moran ve Woolfolk-Hoy 2002, Konuk 2011, Cantekin 2009, Çapri ve Çelikkaleli 2008).

Araştırma sonuçlarımıza göre; erkek beden eğitimi öğretmenlerinin kendilerini kadın beden eğitimi öğretmenlerinden mesleki açıdan daha yeterli buldukları; erkek beden eğitimi öğretmenlerinin kişisel ve mesleki gelişim, öğrenciyi tanıma, öğrenme ve öğretme süreci, öğrenmeyi, gelişimi izleme ve değerlendirme, okul-aile ve toplum ilişkileri, program ve içerik bilgisine bayan beden eğitimi öğretmenlerinden daha fazla sahip olduğu söylenilebilir. Dolayısıyla mesleki yeterlilik duygusuna sahip öğretmenlerin öğrenme ve öğretme faaliyetlerinin başarılı olması ve yeterli eğitimöğretim anlayışına ve bilgisine sahip olduğu şeklinde yorumlanabilir. Burka ve Yuen'e (2008) göre erkeğin egemen olduğu toplumlarda, başarı erkek bireylerle bütünleştirilmiş, kadınlar bu konuda daha çok geri plana itilmiştir. Bu nedenle kadınlar, başarının toplumda dışlanmayı beraberinde getireceğini düşündükleri için başarılı olmaktan kaçınmış ve başarıya sebep olacak işlerini geri plana atmışlardır.

Mesleki deneyim değişkenine göre mesleki yeterlik alt boyutları incelendiğinde mesleki yeterlik ölçeğinin iki boyutunda da istatistiksel açıdan anlamlı bir farklılık tespit edilmiştir. Yapılan analiz sonuçlarına göre Öğrenciyi tanıma alt boyutunda 
mesleki deneyimi 16 ve üzeri olanların puanlarının, mesleki deneyimi 11-15 yıl olanların puanlarından anlamlı düzeyde yüksek olduğu görülmektedir. Program ve içerik Bilgisi boyutunda ise mesleki deneyimi 1-5 yıl olanların puanlarının, mesleki deneyimi 11-15 yıl olanların puanlarından anlamlı düzeyde yüksek olduğu görülmektedir. Bu sonuçtan yola çıkılarak katılımcıların mesleki kıdemleri arttıkça beden eğitimi öğretmeni olma yeterliklerine ilişkin algıları da olumlu yönde geliştiği söylenilebilir. Çakır ve ark. (2004), Çifçili (2007), Terekeci (2010), Sönmez (2003) tarafından yapılan çalışmaların bulgu sonuçları araştırmamızdan elde edilen sonuçlarla benzerlik göstermektedir. Mesleki deneyimi fazla olan beden eğitimi öğretmenlerinin kişisel ve mesleki anlamda kendilerini yeterli algılamaları, öğretimde materyal kullanımının ders dışı sportif etkinlikler ve yarışmalar düzenlemenin önemini kavradıklarını ve program ve içerik bilgisine sahip olduklarını göstermektedir. Ünlü (2008), yaptığı çalışmada tecrübe sahibi öğretmenlerin, öğretecekleri içeriğin aktarımında ve farklı özelliklere sahip öğrencilerin öğretimi konusunda daha fazla deneyim ve beceri kazanmış oldukları sonucuna ulaşmıştır. Bu doğrultuda bakıldığında ise mesleki kıdemi yüksek olan öğretmenlerin yeterlilik algılarının da yüksek olduğu görüşü ortaya çıkmaktadır.

Okulun fiziki alt yapı değişkenine göre mesleki yeterliliğe ait beş alt boyut ele alındığında, aralarında istatiksel yönden anlamlı farklar saptanmıştır. Okul, aile ve toplum ilişkileri, öğrenme ve öğretme süreci, öğrenci bireyi tanıma, öğrenme ve gelişimi izleyip değerlendirme boyutlarında anlamlı farklar olduğu ortaya çıkmıştır. Öksüzoğlu (2009), yapmış olduğu bir araştırma sonucuna göre, beden eğitimi öğretmeni yetiştiren öğretim kurumlarında yeterli düzeyde tesis, saha, malzeme ve araç-gereç bulunduğu sonucuna varmıştır. Bu sonuç, bizim yapmış olduğumuz çalışma sonucuna göre farklılık göstermektedir.

Ayan (2011) araştırmasında öğrenciyi tanıma yeterlik alanıyla ilgili edindikleri bilgileri alanda uygulamaları için yeterli uygulama zamanının ve ortamlarının kendilerine sağlanması gerektiği sonucuna ulaşmıştır. Katrancı, Uygun ve Erdoğan (2010) tarafından yapılan araştırmada da yeterli araç-gerecin bulunduğu bir ortamda öğretmenlik yapmaya yönelik beklentilerinin olduğu sonucuna ulaşılmıştır. Aynı zamanda eğitimde araç gereç kullanımı öğrencilere daha kalıcı eğitim sağladığı, derse olan ilgiyi arttırdığı, derse katılımı üst düzeye taşıdığı ve bu şekilde öğrenilen bilgilerin öğrenciler tarafından gerçek hayata transferini sağladığı görüşü ortaya 
çıkmıştır (Fidan ve Erden, 1998). Ertürk(1991), öğretmenin temel görevinin öğrenci davranışlarını istenilen hedefler doğrultusunda değişikliğe uğratmak olduğunu savunmaktadır. Beden eğitimi öğretmeni, öğrenci bireyin istendik davranışını spor etkinlikleriyle ve bireyin bütünsel gelişimini planlayıp sağlayarak değiştirmektedir. Bu nedenle beden eğitimi öğretmeninin, bireyin gereksinimi karşılama konusunda yeterlilik sahibi olması gerekmektedir (Demirhan 2003). Salman ve ark. (2005) gerçekleştirmiş oldukları bir araştırmaya göre; öğretmenlerin ders verimliliğinin spor salonları ve benzeri tesislerin yetersizliği nedeniyle azaldığı sonucuna ulaşmışlardır. Dwyer ve ark. (2003)' de yaptığı çalışmada beden eğitimi öğretmenlerinin derslerini ve spor aktivitelerini uygulamada, altyapı-tesis yetersizliğinin eksik görüldüğünü ifade etmişlerdir. Dalkıran ve ark. (2004) yaptığı araştırmada beden eğitimi etkinliklerinin amaca uygun yapılamasında tesis ve araç-gerecin önemli yeri olduğunu ifade etmiş̧ir.

Okul içinde sportif faaliyet düzenleme değişkenine göre mesleki yeterlik alt boyutları incelendiğinde mesleki yeterlik ölçeğinin üç boyutunda da istatistiksel açıdan anlamlı bir farklııı tespit edilmiştir. Öğrenmeyi, Gelişimi izleme ve Değerlendirme, program ve içerik bilgisi ve öğrenciyi tanıma boyutlarında anlamlı farkın olduğu belirlenmiştir.

Ünlü ve ark. (2008) yapmış olduğu çalışmada beden eğitimi öğretmenlerinin genellikle okul harici antrenman, maç düzenlemeleri, tören, kutlamalar vb. aktivitelerde bulundukları için öğrencilerle daha fazla zaman geçirmekte ve bu sayede öğrencileri daha yakından tanıma imkanına sahip olduklarını savunmaktadır . Dolayısıyla yapılan bu çalışma sonucu da araştırma bulgularımızı destekler niteliktedir. Çolakoğlu ve Karaküçük (2006) yapmış oldukları çalışma sonuçlarına göre Türkiye'de sporun topluma yaygınlaştırıması konusunda okul sporları ve okul sporlarında beden eğitimi öğretmenlerine önemli görevler düştüğünü ifade etmişlerdir. Pehlivan ve ark. (1994) yapmış olduğu çalışmasında beden eğitimi ve spor öğretmenlerinin okul içi sportif faaliyetler düzenlediği okullar arası yarışmalara katıldıkları sonucuna ulaşmışlardır. Özen ve ark. (2012) tarafından yapılan araştırma sonucuna göre; devlet okulları ve yerel yönetimlerin spora ilişkin tesis ve malzeme yönünden katıımlarının ve sporu yaygınlaştırma çalışmalarına ilişkin olanaklarının yetersiz olduğu tespit edilmiştir. Taşmektepligil ve ark (2006) araştırmalarına göre, 
beden eğitimi dersi, öğrencilerin ilgi duydukları spor dalına yönelmelerinde ve yeni bir spor dalı öğrenmelerinde oldukça büyük bir etkiye sahiptir.

Beden eğitimi öğretmenlerinin yetersiz olduğu konular belirlenerek hizmet içi eğitim etkinlikleri düzenlenerek ve öğretim sürecindeki yenilikler göz önünde bulundurularak öğretmenlerin mesleki yeterlik düzeylerini geliştirmeye yönelik gerek hizmet öncesinde gerekse hizmet içi öğretmenlik formasyonun geliştirilmesine katkı sağlanmalı ve bu etkinliklere katılımın zorunlu olması yönünde çalışmalar yapılmalıdır. Yapılan araştırma özel eğitim kurumlarında da uygulanabilir. Böylelikle resmi eğitim kurumları ile özel eğitim kurumları arasında mukayese yapılabilir. Araştırma kapsamında veri elde etmek amacıyla anket çalışması gerçekleştirilmiştir. Anket çalışmasının yanı sıra farklı yöntemlerde kullanılarak ( görüşme formu, mülakat vb. ) yeni sonuçlar elde edilebilir.

Okulun fiziki alt yapı yetersizliği, beden eğitimi öğretmenlerinin yapacağı çeşitli spor aktivitelerinin olumsuz olarak etkilemekte ve öğrencilerinin bedensel ve zihinsel gelişimini takip etmede ve öğrenciyi tanıma açısından mesleki yeterlilik düzeylerini olumsuz etkilemektedir. Beden Eğitimi derslerinin istenilen amaca ulaşmasında fiziki alt yapı yetersizliği konusunda önlemler alınmalıdır.

\section{Kaynaklar}

Aras, Ö. (2013). İlköğretim kurumları ikinci kademede öğrenim gören öğrenci ve görev yapan beden eğitimi öğretmenlerinin beden eğitimi dersine yönelik görüş ve tutumlarının incelenmesi (Kars ili örneği). Yüksek lisans tezi. Gazi Üniversitesi, Ankara.

Ayan, M. (2011). Eğitim fakültelerinin sınıf öğretmenliği programlarının öğretmenlik mesleği genel yeterliklerini kazandırma düzeyi. Doktora Tezi. Gazi Üniversitesi, Ankara.

Burka, J. B. and Yuen, L. M. (2008). Procrastination: Why you do it, what to do about it now. Reading. America: Published by Da capo press.

Cantekin, Ö. F. (2009). Genel liselerde görev yapan İngilizce öğretmenlerinin mesleki ve iletişimsel yeterlikleri. Doktora Tezi. Gazi Üniversitesi, Ankara.

Çakır, Ö., Erkuş, A. ve Kılıç, F. (2004). Mersin üniversitesi eğitim fakültesi 1999-2000 yılı öğretmenlik meslek bilgisi programının (ÖMBP) çeşitli değişkenler açısından değerlendirilmesi. Mersin: Mersin Üniversitesi Yayınları. 
Çapri, B. ve Çelikkaleli, Ö. (2008). Öğretmen adaylarının öğretmenliğe ilişkin tutum ve mesleki yeterlik inançlarının cinsiyet, program ve fakültelerine göre incelenmesi. İnönü Üniversitesi Eğitim Fakültesi Dergisi, 9 (15), 33-53.

Çifçili, V. (2007). Dershane öğretmenlerinin öğretmen yeterlilik düzeyleri ve mesleki doyumları arasındaki ilişki. Doktora Tezi. İstanbul Üniversitesi, İstanbul.

Çolakoğlu, T. ve Karaküçük, S. (2006). Beden eğitimi öğretmenlerinin okullarda uygulamada karşılaştıkları sorunlar üzerine bir araştırma. Gazi Beden Eğitimi Ve Spor Bilimleri Dergisi, XI. (3), 35-48.

Dalkıran, O. Altıntaş, A. Gündüz, N. Sunay, H. ve Akgül, M. (2004). Ankara ili devlet özel ilk ve orta öğretim okullarındaki beden eğitimi öğretmenlerinin ders dışı etkinliklerinde kapalı spor alanlarını etkin kullanımı üzerine görüşleri. 8. SBD Uluslararası Spor Bilimleri Kongresi, Kemer-Antalya.

Davran, E. (2006). İlköğretim kurumlarındaki öğretmenlik uygulamasının öğretmen adaylarının öğretmenlik yeterliliklerini kazanmaları üzerindeki etkisi (Van ili örneği). Yüksek lisans tezi. Yüzüncü Yıl Üniversitesi, Van.

Demirhan, G. (2003). Dünyada beden eğitimi öğretmeni yetiştirme. Çağdaş Eğitim Dergisi, (300) 13-22.

Dwyer, J.J.M, Allison K.R., Barrera, M., Hansen, B., Goldenberg, E., Boutilier, M.A. (2003). Teachers' perspective on barriers to implementing physical activity curriculum guidelines for school children in Toronto. Canadıan Journal Of Publıc HealthRevue Canadıenne De Sante Publıque.Volume: 94. Issue: 6. Pages: 448-452.

Ertürk, S. (1991). Eğitimde program geliştirme. Ankara: Meteksan Yayınları.

Fidan, N. ve Erden, M. (1998). Eğitime giriş. İstanbul: Alkım Yayınları.

Karakuş, E. (2005). Resmi ortaöğretim kurumlarında beden eğitimi derslerinin uygulamalarında karşılaşılan sorunlara ilişkin öğrencilerin ve beden eğitimi öğretmenlerinin görüşleri ( Kırıkkale ili örneği). Yüksek lisans tezi. Ankara Üniversitesi, Ankara.

Katrancı, M. Uygun, M. ve Erdoğan, Ö. (2010). Sınıf öğretmeni adaylarının öğretmenlik mesleğine yönelik beklentileri ve kaygıları. Hacettepe Üniversitesi, Uluslararası Öğretmen Yetiştirme Politikaları ve Sorunları Sempozyumu II. Ankara. 
Konuk, N. E. (2011). Müzik öğretmeni adaylarının öğretmenliğe ilişkin tutum ve mesleki yeterlik algı düzeylerinin farklı değişkenlere göre incelenmesi. Doktora tezi. Marmara Üniversitesi, İstanbul.

Mirzeoğlu, D. Aktağ, I. ve Boşnak, M. (2007). Beden eğitimi öğretmeni, öğretmen adayı ve beden eğitimi ve spor yüksekokullarında görev yapan öğretim elemanlarının mesleki yeterlik duygusunun karşılaştırılması. Spor Bilimleri Dergisi. 18. (3).

Neale, J. M. ve Liebert, R. M. (1980). Science and behavior an introduction to methods of research. New Jersey: Englewood Cliffs

Öksüzoğlu, P. (2009). Beden eğitimi öğretmen adaylarının öğretmenlik mesleğine ilişkin yeterlik algıları. Yüksek lisans tezi. Mersin Üniversitesi, Mersin.

Özen, G. Koçak, F. Boran, F. Sunay, H. ve Gedikli, N. (2012).Türk spor yönetimindeki mevcut sorunlara ilişkin akademisyenlerin görüşlerinin değerlendirilmesi. Spormetre Beden Eğitimi ve Spor Bilimleri Dergisi. 10(4), 107-116.

Özkan, R. (2010). Türk eğitim sisteminde himayeci değerler. İlköğretim ders kitapları örneği. Ulusalararası İnsan Bilimleri Dergisi. 7 (1), 1124-1141.

Pehlivan, Z. Nejdet, E. ve Dönmez, B. (1994). Okul sporlarının verimliliği üzerine bir araştırma. H.Ü. Spor Bilimleri 3.Ulusal Kongresi Bildiri Özetleri. H.Ü. Spor Bilimleri ve Teknolojisi Yüksekokulu Yayını. Ankara.

Salman, M. N. Çalgın, E. R. ve Salman, S. (2005). Beden eğitimi öğretmenlerinin mesleki sorunlarının cinsiyet faktörü açısından değerlendirilmesi, 4. Ulusal Beden Eğitimi ve Spor Öğretmenliği Sempozyumu, Bursa.

Seçkin, A., \& Başbay, M. (2013). Beden eğitimi ve spor öğretmeni adaylarının öğretmenlik mesleğine ilişkin öz-yeterlik inançlarının incelenmesi. Electronic Turkish Studies, 8(8), 253-270, Ankara.

Seçme, T. (2008). Beden eğitimi ve spor öğretmenlerinin iş doyum düzeylerinin belirlenmesi (Afyonkarahisar örneği). Yüksek lisans tezi. Afyonkarahisar Kocatepe Üniversitesi, Afyonkarahisar.

Sönmez, V. (2003). Öğretmenlik mesleğine giriş. Ankara: Anı Yayıncılık.

Sünbül, A. M., ve Arslan, C. (2007). Öğretmen yeterlik ölçeğinin geliştirilmesi ve bir araştırma örneği. Osmangazi Üniversitesi Sosyal Bilimler Dergisi, 1, 1-13. 
Taşmektepligil, Y. Yılmaz, Ç. İmamoğlu, O. ve Kılcıgil, E. (2006). İlköğretim okullarında beden eğitimi ders hedeflerinin gerçekleşme düzeyi. Spormetre Beden Eğitimi ve Spor Bilimleri Dergisi, 4, 139-147, Ankara.

Terekeci, P. (2010). Illköğretim birinci kademe sınıf öğretmenlerinin rehberlik uygulamaları ve öğretmen yeterlilikleri arasındaki ilişkinin incelenmesi. Yüksek lisans tezi. Uşak Üniversitesi, Uşak.

Tschannen-Moran, M., \& Woolfolk Hoy, A. (2002, April). The influence of resources and support on teachers' efficacy beliefs. In annual meeting of the American Educational Research Association, New Orleans, LA.

Ünlü, H. Sünbül, A. M. ve Aydos, L. (2008). Beden eğitimi öğretmenleri yeterlilik ölçeği geçerlilik ve güvenirlik çalışması. Ahi Evran Üniversitesi Kırşehir Eğitim Fakültesi Dergisi 9 (2),23-33.

Ünlü, H. (2008). Beden eğitimi öğretmenlerinin yeterlikleri ve sınıf yönetimi davranışları. Doktora tezi. Gazi Üniversitesi, Ankara. 